\title{
Digital Assets: The Idea of Indonesian Property Law Reform and Its Potential as a Collateral Object
}

\author{
Teguh Tresna Puja Asmara ${ }^{1}$, Lastuti Abubakar2, Tri Handayani3 \\ ${ }^{1}$ Faculty of Law, Padjadjaran University, Indonesia. E-mail: teguhtresna95@gmail.com \\ 2 Faculty of Law, Padjadjaran University, Indonesia. E-mail: lastuti62abubakar@gmail.com \\ ${ }^{3}$ Faculty of Law, Padjadjaran University, Indonesia, E-mail: tri.handayani@unpad.ac.id
}

\begin{tabular}{|c|c|}
\hline ARTICLE INFO & ABSTRACT \\
\hline $\begin{array}{l}\text { Keywords: } \\
\text { Digital Asset; Social } \\
\text { Media; YouTube; Asset; } \\
\text { Collateral } \\
\text { How to cite: } \\
\text { Asmara, T.P.A., } \\
\text { Abubakar. L., and } \\
\text { Handayani, T. (2019). } \\
\text { Digital Assets: The Idea of } \\
\text { Indonesian Property Law } \\
\text { Reform and Its Potential } \\
\text { as a Collateral Object, } \\
\text { Hasanuddin Law Review, } \\
\text { 5 (3): 278-288 } \\
\text { DOI: } \\
\text { 10.20956/halrev.v5i3.1735 }\end{array}$ & $\begin{array}{l}\text { Digital assets in the broadest sense can be interpreted to cover all } \\
\text { electronic assets including social media accounts. Nowadays, besides } \\
\text { being used to interaction, social media accounts can also be utilized to } \\
\text { gain income or material benefits. In addition, social media accounts } \\
\text { are generally handled by influencers with abundant followers. One of } \\
\text { the social media used by influencers on the internet is YouTube. The } \\
\text { social media actors on YouTube are referred to as YouTubers or } \\
\text { content creators. This research is a normative juridical legal research } \\
\text { with the descriptive method of analysis. The result of the study shows } \\
\text { that YouTube accounts as digital assets in practice can be used as } \\
\text { assets in business activities. This is proven by the existence of a } \\
\text { YouTuber or content creator who sells his account for charity or } \\
\text { commercial purposes. In the future, YouTube accounts can potentially } \\
\text { be a digital asset that can be used as a collateral object due to its } \\
\text { economic value. Nevertheless, based on the property of law in } \\
\text { Indonesia, YouTube social media accounts as a digital asset cannot be } \\
\text { qualified as an asset yet, therefore a redefinition, a reconceptualization } \\
\text { and a reform of the property of law are considered necessary. }\end{array}$ \\
\hline
\end{tabular}

Copyright (C) 2019 HALREV. All rights reserved.

\section{Introduction}

The global progression has led to the development of many aspects in our lives. Technology, is one of the aspects that grown rapidly. It can be seen from the increasing numberof internet used in daily lives, both with the aim of interaction and business. Through the diffusion of internet in the society, there has been a change of concept in interaction and business activities.

Business activities in the context of the internet, are activities that generate profit with economic value based on the content of social media accounts. People who use their social media accounts for business purposes or to obtain revenue are often users who have many followers, and are often referred to as influencers. Influencers are people or 
figures on social media who have a large or significant number of followers and the things they convey on social media can influence or respond to the behaviour of their followers. ${ }^{1}$ For instance, the influencers that are often encountered currently are YouTubers or content creators.

Social media accounts are one of the forms of digital assets. In a broad sense, digital assets include all virtual property someone may have in cyberspace, as well as e-mail, digital photos, videos, tweets, texts, songs and e-books, and it can also be online accounts for websites or social media programs such as Facebook, LinkedIn, and so forth. ${ }^{2}$

Digital assets mean text, images, multimedia information, or personal properties stored in a digital format, whether stored on a server, computer, or other electronic devices which may exist as technology develops, and regardless of the ownership of the physical device upon which the digital asset is stored. Digital assets include, without limitation, any words, characters, codes to access the digital assets. It can be classified as numerous different ways, and the types of properties and accounts are constantly changing. (A decade ago, who could have imagined the ubiquity of Facebook? People may accumulate different categories of digital assets: personal, social media, financial, and business. An individual may also have a license or ownership interest in the asset. Although there are some overlapping, of course, clients may need different plans for each. ${ }^{3}$

Based on the above definition, it can be concluded that a digital asset includes text, images, multimedia information, or personal property stored in a digital format, whether stored on a server, computer, or other electronic devices that was already exists or will be present with the development of technology, regardless of ownership of physical devices where digital assets are stored. Digital assets include, without limitation, words, characters, codes, or the need for any contractual rights to access these digital assets.

As an illustration, YouTube social media account, which is one form of digital asset, can collect various categories of digital assets itself, such as personal digital assets, social media, finance, and business. An individual can also have a license or property ownership interest in the digital asset.

Nowadays, YouTube social media accounts are being used by people to earn material benefit by making various kinds of creative content. However, not all YouTube accounts are profitable. Based on YouTube guidelines, only YouTube accounts that get 4 thousand broadcasts in the last 12 months and 1.000 subscribers will gain income. ${ }^{4}$

If a YouTube account meets these requirements, subsequently the YouTuber or content creator can monetize their account as a media for advertisement from AdSense. Rough calculations that are used by people in general refers to income of 1 dollar per 1.000 views Revenue per Mille impression (RPM), although the number of RPMs can be higher or much lower than that. The calculation of income can also be calculated based on the

\footnotetext{
${ }^{1}$ Novi Tri Hariyanti and Alexander Wirapraja. (2018). “Pengaruh Influencer Marketing Sebagai Strategi Pemasaran Digital Era Moderen (Sebuah Studi Literatur)". Jurnal Eksekutif, 15 (1): 131-146.

${ }^{2}$ Richard Weiland. (2014). Planning for and Administering Digital Assets. Georgia : Clark Wilson LLP, p. 1.

${ }^{3}$ Gerry W. Beyer. (2015). “Web Meets the Will: Estate Planning for Digital Assets". Journal of Estate and Tax Planning, 42 (3): 28-41.

${ }^{4}$ Youtube Creator Accademy. (2018). Pelajaran: Berapakah penghasilan yang saya dapatkan?. Available online from: https://creatoracademy.youtube.com/page/lesson/m10n-analytics?hl=id\#strategies-zippylink-3 (accessed 13 January 2019)
} 
number of viewers multiplied by 1 /IDR 1.000. This is commonly called Cost Per Mille (CPM). For example, in one YouTube account, a user gains 1.000 .000 viewers, in that case the user has the right to earn IDR 10.000.000.

Thus, social media accounts that will be reviewed in this study are only limited to YouTube social media accounts. YouTube accounts in practice can be used as an asset for business activities. There are some users who have started selling their accounts for various purposes such as charity and commercial business. What becomes a question is, whether a social media account like YouTube is categorized as an "asset" that can be qualified as a collateral object according to the property of law in Indonesia?

Based on Article 499 of the Indonesian Civil Code, it is stated that the law interprets assets as all goods and rights which can be the subject of property. Assets can be tangible goods (lichamelijk), intangible goods (onlichamelijk), movable and immovable goods, consumable goods (vebruikbaar) and non-consumable goods (onverbruikbaar), existing goods (tegenwoordigezaken) and goods that will still exist (toekmstigezaken). Whereas in Articles 503 and 504 of the Indonesian Civil Code, the types of assets are divided into tangible and intangible assets, movable and immovable assets, movable assets that are consumable and non-consumable.

YouTube social media accounts as part of digital assets are intangible. In principle, YouTube accounts cannot be directly felt by the human senses. It cannot be seen by human senses in a tangible manner and also cannot be felt by using human sense of taste. Even though it does not have a tangible form, in reality, the assets of social media accounts are widely used by people in their daily lives and have an economic value.

According to the Indonesian Civil Code, there are several elements related to intangible assets which are legal objects, part of assets, can be owned, have no body, and in the form of rights. Based on the elements of assets listed in the Indonesian Civil Code, it can be concluded that YouTube social media accounts are not a part of assets that mentioned above. This is because YouTube social media accounts as intangible assets are not rights.

The definition of assets in Indonesia still refers to Article 499 of the Indonesian Civil Code, however in its development in the Netherlands, the definition of an asset itself has already been expanded. In Nieuw Burgerlijk Wetboek (NBW) Boek 3 Titel 1 Article 1 states that "goederen zijn alle zaken en alle vermogenrechten" which means that assets consist of all goods and all other property rights. Furthermore, NBW states that "Goederen zijn alle actieven vermogen bestandelen" which means that goods are all active elements of assets. Thus, NBW has expanded the definition of assets, not only covering goods and rights that can be controlled by rights of ownership, but also includes all active elements of assets and eliminates the "can be owned" character. 5 Therefore, a redefinition, reconceptualization and reform of the property of law in Indonesia deemed necessary so that digital assets, in this case YouTube social media accounts, can be categorized as assets and in the future can be used as collateral objects.

\section{Method}

The research method used in this article use a normative juridical approach, a legal research method which prioritizes ways of researching library materials or secondary data material in the form of positive law governing digital assets, materials, and

\footnotetext{
${ }^{5}$ Lastuti Abubakar. (2015). “Telaah Yuridis Perkembangan Lembaga Dan Objek Jaminan (Gagasan Pembaruan Hukum Jaminan Nasional)". Buletin Hukum Kebanksentralan, 12 (1) : 1-16.
} 
collaterals. This research is a normative juridical legal research with the descriptive method of analysis. This is a descriptive analytical research, which describes the facts of the data obtained based on reality, particularly activities related to digital assets, materials, and collaterals in Indonesia. These facts are then analysed by the applicable law and conclusions are drawn.

\section{The Position of Social Media Account as a Digital Asset Reviewed from the Indonesian Property of Law}

The existence and function of assets changes as time progresses, it is shifting from the conventional form into a digital form, where the asset is no longer in a physical form. This asset is commonly known as digital assets. Digital assets do not have a form that can be felt by the human senses. Digital assets cannot be seen physically by the human senses and cannot be felt by using the sense of human taste. Even though it does not have a real form, digital assets are widely used by human in their daily lives and can even have economic value.

The use of this digital asset is limited to only being used in cyberspace, namely the cyber world. Although digital assets are only existand useful in cyberspace, these digital assets can have an impact on various aspects of people's lives regardless of their intangible existence.

The effects of the existence of digital assets areaffecting to the social, economic and even cultural aspects. One of the most widely used digital assets nowadays is social media. With the presence of social media, communication among people experience changes from conventional to digital interactions. In addition, in the field of business, social media can also be utilized for gaining income. However, in its development, social media accounts as digital assets raise a legal problem, which are related to itsstatus whether it is an asset or not.

Social media accounts as digital assets are intangible or have no body in the real essense. Regulation regarding intangible assets in the property of law in Indonesia, can be found in the regulation of assets in Book II of the Indonesian Civil Code. Assets, according to Article 499 of the Indonesian Civil Code, are each item and each right that can be controlled by rights of ownership. Whereas according to some experts, the rights stated in this Article are also interpreted as intangible assets, as the opinion which states that the Indonesian Civil Code word zaak is used in two meanings, first in the sense of tangible goods, and second in terms of parts of assets. In this second meaning (as part of assets) which includes zaak as other than tangible goods, also includes certain rights as intangible goods.

The kinds of intangible assets according to the Indonesian Civil Code are explicitly regulated and described in Article 503 of the Indonesian Civil Code, which states that each asset is bodied or not bodied. Based on the statement, intangible assets are described as assets that are not bodied.

There are several elements that can become the basis in determining whether something can be categorized into assets or not. The first element is a legal object. Assets, as legal objects, are all things that are useful for legal subjects which includes both human and legal entities, and which can be the subject of a legal relationship because it can be controlled by the subjects. Social media accounts as part of digital assets have various functions and uses for both social and business-oriented users. 
Currently, social media accounts can also create relationships or legal actions, which is evident by the case of a YouTuber or content creator who sells his account for charity or commercial purpose. Based on this activity, it can be concluded that social media accounts fulfil elements as legal objects and as a part of assets due to its economic value.

In terms of its authority, social media accounts are exclusive. It can only be accessed by using passwords owned by influencers. Based on this matter, social media accounts fulfil the requirements that it can be controlled or owned. Social media accounts as digital assets are intangible and exclusive properties, ${ }^{6}$ thus fulfilling requirements as a bodied or not bodied asset. The last element in assets, especially intangible assets, is in the form of rights. Social media accounts as digital assets are not rights, but have their own forms limited in computer systems and the internet (cyber world).

Based on the above study, it can be concluded that YouTube social media accounts as digital assets are not assets as stipulated in the Indonesian Civil Code. Although it has fulfilled the elements of assets in general, YouTube account, which is a legal object, part of assets, can be owned, and does not have a body, is not a right. YouTubeaccounts has fulfilled one of the elements, namely a part of assets, where YouTube social media accounts has economic value. It is necessary to reform the property of law in Indonesia concerning on the property of law. This is in line with the reform of the property of law at NBW, which defines that assets not only includes goods and rights that can be controlled by rights of ownership, but also includes all active elements of assets and eliminates the "can be owned" characteristic.

\section{The Comparison of the Regulation of Assets in the Indonesian and Dutch Legal Systems}

Assets in the legal system in Indonesia are regulated in Book II of the Indonesian Civil Code. Assets according to Article 499 of the Indonesian Civil Code on Assets, are all goods and rights that can belong to people (assets of ownership). In the Indonesian Civil Code, there are two terms concerning assets, namely assets (zaak) and goods (goed). In general, what is interpreted as an asset in the form of tangible assets, parts of assets, or in the form of rights are all things that can be controlled by humans and can be used as legal objects.

Based on the Indonesian Civil Code on Assets, assets can be distinguished into tangible goods (lichamelijk), intangible goods (onlichamelijk), movable and immovable goods, finished goods (vebruikbaar) and unfinished goods (onverbruikbaar), existing goods (tegenwoordigezaken) and goods that will still exist (toekmstigezaken).

The governing law related to the asset is called the property of law which is a translation from the Dutch language, zakenrecht. The property of law consists of all legal rules governing what defines assets and regulating the rights of assets. The property of law also regulates the definition of assets, distinguishes the types of assets, and its largest part regulates the kinds of material rights.

In the asset there is inherent rights such as rights of ownership, bezit, and material rights over material belonging to someone else. ${ }^{7}$ The most powerful rights include rights of

\footnotetext{
${ }^{6}$ David Nelmark. (2004). “Virtual Property: The Challenges of Regulating Intangible, Exclusionary Property Interests such as Domain Names". Northwestern Journal of Technology and Intellectual Property, 3 (1): 1-11.

${ }^{7}$ Neng Yani Nurhayani. (2015). Hukum Perdata. Bandung: CV Pustaka Setia, p. 192.
} 
ownership. Rights of ownership are absolute rights attached to an asset. Article 570 of the Indonesian Civil Code states that rights of ownership are the rights to fully enjoy the use of an asset and to do as freely as possible for the asset, provided that it does not contradict with the law on public order and morality and does not cause interference to others without omitting the possibility of rights to public interest. Rights of ownership can be concluded as the most important rights attached to an asset, thus rights of ownership are unparalleled.

The stipulation states that zaak or assets are used not in the sense of tangible goods, however in the sense of "part of assets". In the Indonesian Civil Code, the words zaak are used in two meanings, first in the sense of tangible goods, second in terms of parts of assets. In this second sense (as part of assets) includes zaak as other than tangible goods, and certain rights as intangible goods.

From the explanation above, it can be concluded that the notion of assets are anything that can be owned or made into an assets of ownership. The scope is very broad, due to the terms goods (goed) and rights (recht) being alongside the term of assets (zaak). However, regarding the terms of assets and goods, the Indonesian Civil Code does not consequently distinguish them because they often interchangeably use and confuse the two meanings.

In NBW or the Dutch Civil Code (DCC) there are differences pertaining the definition of goods (goed) and assets (zaak). In Book 3 Title 3.1 Section 3.1.1 Article 3: 1 concerning the Definition of property as a legal object, it is stated that Property (or assets) comprises all things and all other property rights and Article 3: 2 concerning Definition of Things mentioned that Things are tangible assets that can be controlled by humans. Based on the article, property is translated as goed and things are translated as zaak. According to DCC, goed has a broader understanding of the term zaak (things) because goods are all objects and all assets, while things are merely tangible assets that can be controlled by humans.

Concerning possesion (bezit) of movable and immovable assets regulated in Article 1977 Indonesian Civil Code determines that bezit is absolute ownership, however there are not for immovable assets (people who control immovable assets are not necessarily owners of these assets). This also affects the delivery, that according to Article 612 of the Indonesian Civil Code for the delivery of movable assets, can be carried out with actual delivery (feitelijke levering). Actual delivery is at the same time juridical delivery (juridische levering). Whereas according to Article 616 of the Indonesian Civil Code, the delivery of immovable assets is carried out through the announcement of the deed concerned in the manner specified in Article 620 of the Indonesian Civil Code, for example, to record it in the register. As for the delivery of intangible receivables, it is regulated under Article 613 Indonesian Civil Code.

In the DCC, the distinction concerning movable and immovable assets is also regulated in the Book 3 Title 3.1 Section 3.1.1 Article 3: 3 concerning Immovable and movable which states that 'Immovable' is the land, the not yet mined minerals, the plants are connected to the land, and the buildings are permanently attached to the land, either they are all things that are not immovable. This distinction has consequences for several points. For example, in relation to the issue of delivery (transfer) as stipulated in Article 3:89 concerning Formal delivery of immovable property and Article 3:90 concerning Formal delivery of movable property. 
According to this stipulation, an immovable property requires formal transfer using notarial deed to be registered. Whereas in movable properties it is only needed in certain circumstances, for example to provide strong possession in cases that are prone to disputes such as constitutum possesorium (transfer of ownership rights to the creditor while the item is still in the debtor's hands).

Concerning the acquisition of material rights in the Indonesian Civil Code regulated in Article 584 regarding the way to obtain ownership rights, it is stated thatownership of assets cannot be acquired in any manner other than by appropriation, attachment, prescription, legal or testamentary succession, and by assignment or delivery pursuant to a transfer of legal title, originating from the individual who was entitled to dispose of the property.

In the Netherlands, the means for obtaining and losing material rights is regulated in DCC Book 3 Title 3.4 Section 3.4.1 Article 3:80 concerning Acquisition under universal title and loss rights which states that a person may acquire property under universal title or under particular title. Property is acquired under universal title through inheritance by succession, through marriage in a community of property, through a merger of two or more legal people, through a split up of a legal person and through the approval of a transfer plan as referred to in Articles 3:1591, 3159p and 3:159 of the Financial Supervision Act. A person acquires property under particular title through a transfer, a prescription, an expropriation (compulsory purchase) or through any other way provided by law in order to acquire specific types of property rights. And A person may lose property in the ways set for this purpose by law for each type of property.

In the case of security rights in Indonesia, based on the Indonesian Civil Code, an asset can be established with real security rights including Pawn (Article 1150 to Article 1160 Indonesian Civil Code), Fiduciary (Law No.42 of 1999 concerning Fiduciary), Mortgage (Article 1162 to 1232 Indonesian Civil Code), Mortgage Rights (Law No. 4 of 1996 concerning Encumbrance Right Over Land and Land Related Object - UUHT), and Warehouse Receipt (Law No. 9 of 2011 Concerning Amendments to Law No.9 of 2006 Concerning Warehouse Receipt System).

In the Netherlands, only two things are known regarding collateral, namely Pledge and Mortgage. Based on Book 3 Title 3.9 Section 3.9.1 Article 3: 227 DCC about Apledge and a mortgage are real security rights. Pledge and Mortgage are used to give the proprietor (pledgee and mortgagee) the title to recover his financial debt-claim from the sale proceeds of the encumbered asset prior to all other creditors of the person to whom the encumbered asset belongs. Article 3: 227 states that when a real security right is established on an immovable property, it is called a mortgage; when established to any other property, it is called a pledge. The difference between a pledge and a mortgage is from the way it is established. Possessory pledge, as stipulated in Article 3: 236, is carried out by the delivery of goods or securities in the power of pledge. Non-possessory pledge, as stipulated in Article 3: 237, is carried out by notarial deed and registered afterward. This applies as well to Mortgage, as stipulated in Article 3: 260, which is carried out by notarial deed and registered afterward.

Based on the explanation of the comparison of Indonesian andDutch Legal System above, there are several differences and developments regarding assets. The most principle thing about the development of assets is the definition of the asset itself, wherein the DCC states that the goods consists of all assets and all property rights as well as all active elements of assets. DCC has expanded the meaning of assets, which not only includes goods and rights that can be controlled by ownership rights, however it 
includes all the active elements of assets and eliminates the "can be owned" character. Therefore, it is necessary to be a redefinition, reconceptualization and reformation of the property of law in Indonesia so that digital assets, specifically YouTube social media accounts, can be categorized as assets and in the future, it can be used as collateral objects.

\section{The Potential of Digital Assets (YouTube Social Media Account) as a Collateral Object in the Indonesian Security of Law Perspective}

In the Netherlands only two things are known about collateral, namely Pledge and Mortgage. Based on Book 3 Title 3.9 Section 3.9.1 Article 3: 227 DCC about A 'pledge' and a 'mortgage' are real security rights. Pledge and Mortgage are used to give the proprietor (pledgee and mortgagee) a return on accounts that precede other creditors. Article 3: 227 states that when a collateral is established on an immovable property, it is called a mortgage; when established to any other property, it is called a pledge. The difference between a pledge and a mortgage is from the way it was established. Possessory pledge, as stipulated in Article 3: 236, is carried out by the delivery of goods or securities in the power of pledge. Non-possessory pledge, as stipulated in Article 3: 237, is carried out by notarial deed and registered afterward. This applies as well to Mortgage, as stipulated in Article 3: 260, which is carried out by notarial deed and registered afterward.

Collateral is a term derived from the Dutch word "zekerheid" or "cautie" means the ability of the debtor to fulfil or repay his debt to creditors, which is carried out by holding certain assets of economic value as a loan or debt received by the debtor against creditor. The terms "zekerheid" or "cautie" also cover generally the ways the creditor guarantees that the bill can be fulfilled, besides that it also contains the liability of the debtor. Article 1 number 23 of Law No. 10 of 1998 concerning the amendment to Law No. 7 of 1992 concerning on Banking (Banking Law) states that collateral is an additional security that is given by debtor to banks in the context of providing credit facilities or financing based on sharia principles.

Collaterals in general are regulated in Articles 1131 and 1132 of the Indonesian Civil Code which stipulates that all debtor rights both movable and immovable, both existing and future ones will be borne by all the agreements. Collateral in its construction, is an additional security to obtain a credit facility from the bank.

In the perspective of banking law, collateral is divided into 2 (two) types, namely primary collateral and additional collateral. In Article 8 paragraph (1) of the Banking Law, it is explained that primary collaterals consist goods, securities, or guarantees that are directly related to the assets financed with the credit in question, such as goods purchased with collateralized loans, projects financed with the credit concerned, as well as debtor; while additional collaterals consists of goods, securities, or guarantees that are not directly related to the assets financed with the credit in question, which is added as collateral.

A collateral is a responsibility given by a debtor and/or a third party to a creditor to guarantee his obligations in an agreement. In accordance to the definition of collateral above, it can be concluded, that collateral is an insurance against the loan facility provided by the debtor to the creditor until the loan is paid in full. The collateral can be in the form of material and individual and if the debtor is defaulted, the collateral in the form of material can be valued with money, while the individual collateral must be 
responsible for the loan. In other words, it can be said that security has function as a means of fulfilling debt.

Collateral in a juridical perspective are interpreted as an effort to provide legal certainty to creditors (the rightful party) that the debtor (the obligated party) will carry out their obligations. ${ }^{8}$ In addition to Article 1131 and 1132 of the Civil Code, collaterals are also regulated in several laws including Law No. 4 of 1996 concerning Encumbrance Right Over Land and Land Related Object (UUHT), Law No. 42 of 1999 Concerning Fiduciary (Fiduciary Law), Law No. 9 of 2011 concerning Amendments to Law No. 9 of 2006 concerning Warehouse Receipt System (Warehouse Receipt Law), and Law No. 1 of 2016 concerning Securities (Security Law).

Assets that can be used as collateral objects are assets in a juridical sense, as stipulated in Article 499 of the Indonesian Civil Code, namely each goods and every right that can be controlled by rights of ownership. This article affirms that what is meant by assets here consists of goods and rights that can take the form of rights to tangible goods, such as securities or intellectual property rights including copyright, patent rights, and branding rights.

Intangible assets in Indonesian property of law are regulated in Article 503 of the Indonesian Civil Code which states that each property is bodied or not bodied. In this stipulation, intangible assets are explained as non-bodied assets.

Based on the formulation contained in the Indonesian Civil Code, assets that are not tangible even though they do not have a form, are rights that are placed on assets that are tangible. Thus, intangible assets actually exist and are attached to a certain benefit for a certain asset that has a form.

The definition of tangible asset are all tangible goods that can be captured by the senses, while intangible assets are certain rights that can be used as assets of ownership rights, such as rights to interest, income, collection, and so on. ${ }^{9}$ In other words, an intangible asset is not an asset that has a real form or form that can be felt by human senses. Something in the form of certain rights, which stipulated in the Indonesian property of law Article 499 and 503 of the Indonesian Civil Code, is also recognized as assets.

YouTube social media accounts as digital assets do not have a form that can be felt by the human senses. These assets cannot be seen by the human sight in real terms and cannot be felt by using the human sense. Although it does not have a real form, these virtual properties are widely used by humans in their daily lives and have economic value.

Nowadays, YouTube social media accounts are being used by people to gain economic revenue by making various kinds of creative content. YouTube social media accounts in practice can be used as assets of business activities. There are some people who have started selling their accounts for various purposes such as charity and buying and selling goods.

The regulation regarding YouTube social media accounts as digital assets is not yet adequate. The Indonesian legal system itself has not provided yet a clear regulation regarding YouTube social media account as a digital asset. However, based on a comparison with the property of law in the Netherlands, it can be concluded that

\footnotetext{
${ }^{8}$ Lastuti Abubakar, Op. Cit., p. 2.

${ }^{9}$ Neng Yani Nurhayani, Op. Cit, p. 163.
} 
YouTube social media accounts as digital assets can be referred to as assets because they are a part of assets.

A redefinition, reconceptualization and reform of property of law in Indonesia are essentially needed. This is required to accommodate developments in the form of assets that exist in society. Following the reform of the property of law, YouTube social media accounts as intangible assets but not rights, can be called as an asset. In addition, YouTube accounts can also be a collateral object due to its economic value.

The proper collateral regulation in accommodating security for YouTube social media accounts as intangible moving assets is a fiduciary regulation. This is based on Article 1 point 2 of the Fiduciary Law which states that Fiduciary are guaranteed rights for movable assets, both tangible and intangible as well as immovable assets, especially buildings that cannot be burdened with liabilities as referred to in Law No. 4 of 1996 concerning Mortgage right. In addition, the fiduciary institution also allows fiduciary givers to control the collateral objects, to carry out business activities financed by loans using fiduciary.

\section{Conclusion}

YouTube social media accounts as digital assets are not assets as stipulated in the Indonesian Civil Code. This is because even though YouTube accounts has fulfilled the elements of assets in general, which are legal object, a part of assets, can be owned, and does not have a body, however it is not a right. YouTube social media account has fulfilled one of the elements of the assets, which is a part of asset, because YouTube social media accounts have the economic value.

YouTube social media accounts as digital assets have potential economic value as collateral objects. However, there needs to be a redefinition, reconceptualization and reform of the property of law in Indonesia. This is in line with the reform of the property of law in NBW, which defines assets as not only including goods and rights that can be controlled by rights of ownership, but also includes all active elements of assets and eliminates the "can be owned" characteristic.

The proper collateral regulation in accommodating security for YouTube social media accounts as intangible moving assets is a fiduciary institution. This is because fiduciary can be established on movable and immovable assets, tangible and intangible, especially buildings that cannot be burdened by mortgages. Fiduciary institutions also allow fiduciary givers to control the collateral objects, to carry out business activities financed by loans using fiduciary

\section{References}

David Nelmark. (2004). "Virtual Property: The Challenges of Regulating Intangible, Exclusionary Property Interests such as Domain Names". Northwestern Journal of Technology and Intellectual Property, 3 (1): 1-11.

Gerry W. Beyer. (2015). “Web Meets the Will: Estate Planning for Digital Assets”. Journal of Estate and Tax Planning, 42 (3) : 28-41.

Lastuti Abubakar. (2015). “Telaah Yuridis Perkembangan Lembaga Dan Objek Jaminan (Gagasan Pembaruan Hukum Jaminan Nasional)". Buletin Hukum Kebanksentralan, 12 (1) : 1-16. 
Neng Yani Nurhayani. (2015). Hukum Perdata. Bandung: CV Pustaka Setia.

Novi Tri Hariyanti and Alexander Wirapraja. (2018). "Pengaruh Influencer Marketing Sebagai Strategi Pemasaran Digital Era Moderen (Sebuah Studi Literatur)". Jurnal Eksekutif, 15 (1) : 133-146.

Richard Weiland. (2014). Planning for and Administering Digital Assets. Georgia : Clark Wilson LLP.

Youtube Creator Accademy. (2018). Pelajaran: Berapakah penghasilan yang saya dapatkan?. Available online from: https://creatoracademy.youtube.com/page/lesson/ m10n-analytics?hl=id\#strategies-zippy-link-3 (accessed January 13, 2019)

\section{Conflict of Interest Statement:}

The author(s) declares that the research was conducted in the absence of any commercial or financial relationships that could be construed as a potential conflict of interest.

Copyright (C) 2019 HALREV. All rights reserved. 